Revista de Derecho

de la Pontificia Universidad Católica de Valparaíso

53 (segundo semestre de 2019)

[pp. 67 - 98]

\title{
REVISIÓN DE LOS CONTRATOS ADMINISTRATIVOS: EL ADECUADO EQUILIBRIO ENTRE POTESTADES EXORBITANTES Y LOS DERECHOS CONTRACTUALES*
}

[Review of administrative contracts: the appropriate balance between exhortative powers and contractual rights]

\section{Juan Carlos Flores Rivas** \\ Universidad de los Andes}

\begin{abstract}
Resumen
Este artículo tiene por objetivo analizar los requisitos y condiciones que deben concurrir para mantener el equilibrio económico y financiero en los contratos administrativos ante cambios derivados del ejercicio de potestades públicas de la Administración contratante. Se analizan las modificaciones unilaterales del contrato introducidas por el Estado contraparte contractual, como aquellas que se sustentan en la dictación de normas generales emitidos por otros órganos del Estado, como el poder legislativo o el poder ejecutivo en el ejercicio de la potestad reglamentaria. Por último, se estudian los cambios contractuales derivados de hechos ajenos a la voluntad de las partes, imprevisibles e irresistibles que vuelven el cumplimiento de las obligaciones contractuales excesivamente oneroso.
\end{abstract}

\section{Palabras clave}

Derecho administrativo - contratos administrativos - equilibrio contractual - potestades exorbitantes.

\section{Abstract}

The purpose of this article is to analyze the requirements and conditions that must be met in order to maintain the economic and financial balance in administrative contracts in the face of changes arising from the exercise of public powers of the Contracting Authority. Unilateral contract modifications introduced by the contracting State are analyzed, such as those based on the issuance of general rules issued by other State bodies, such as the legislative power or the executive power in the exercise of regulatory power. Finally, we study the contractual changes derived from events unrelated to the will of the parties, unforeseeable and irresistible that make the fulfillment of contractual obligations excessively onerous.

\section{KeYwords}

Administrative Law - administrative contracts - contractual equilibrium - exorbitant powers.

Recibido el 19 de febrero de 2019 y Aprobado el 1 de julio de 2019.

* Algunas ideas generales de este artículo han sido plasmadas en el libro homenaje al profesor José Luis Martínez López-Muñiz. Cfr., Flores Rivas, Juan Carlos, Revisión de contratos administrativos. El adecuado equilibrio entre potestades exorbitantes y los derechos contractuales, en Laguna de Paz, José Carlos - Sanz Rubiales, Iñigo - De los Mozos y Touya, Isabel María (coords.), Derecho Administrativo e integración europea. Estudios en Homenaje al profesor José Luis Martínez López-Muñiz (Madrid, Editorial Reus, 2017), pp. 1013-1022. 


\section{INTRODUCCIÓN}

La contratación administrativa es fruto de acuerdos público-privados entre órganos de la Administración del Estado y particulares, asumiendo estos la calidad de cooperadores en la satisfacción de necesidades públicas. En este contexto, los contratos administrativos suelen estar configurados como acuerdos de voluntades de largo plazo, de ejecución diferida o de tracto sucesivo. De esta forma, en la contratación administrativa se exige un elevado estándar de seguridad jurídica, que permita al contratista enfrentar las contingencias económicas, financieras, tributarias, tecnológicas, y sobre todo administrativas que influyen sobre el objeto, el precio y los demás requisitos y condiciones que informan el pacto inicialmente celebrado.

La seguridad jurídica, la igual repartición de las cargas públicas y la indemnidad patrimonial de los administrados exigen que en los contratos administrativos -cuyos efectos se defieren en el tiempo-se incorporen expresa o tácitamente mecanismos que morigeren y atenúen las contingencias contractuales y restablezcan el equilibrio económico financiero del contrato, con la finalidad de mantener la continuidad en la satisfacción de la necesidad pública envuelta en el contrato.

Lo anterior constituye una variable que debe estar presente en cada contrato administrativo, no obstante, su objeto y forma de solventar el precio. De este modo, para que las condiciones inicialmente convenidas subsistan los embates de las contingencias contractuales y el objeto contractual no se desvirtúe más allá de lo esencialmente pactado por las partes, se hace necesario que existan reglas claras en el proceso de contratación, desde las tratativas previas hasta la celebración del contrato administrativo. Asimismo, deben ser prístinas las reglas de interpretación, aplicación y ejecución del mismo, a fin que sean razonables y respondan a criterios de buena fe y justicia contractual.

El presente artículo tiene por objetivo determinar la existencia, requisitos y condiciones exigibles en nuestro ordenamiento jurídico para mantener un adecuado equilibrio económico y financiero en los contratos administrativos ante cambios derivados del ejercicio de potestades públi-

** Doctor en Derecho. Profesor de Derecho Administrativo, Universidad de los Andes, Santiago, Chile. Dirección Postal: Mons. Álvaro del Portillo 12.455, Las Condes, Santiago. jcflores@uandes.cl. Este trabajo forma parte del Proyecto Fondecyt de Iniciación No11180639, "Recepción del principio de equilibrio económico y financiero en los contratos administrativos de suministro y prestación de servicios, de construcción de obra pública y de concesión de obra pública”, del que el autor es investigador principal. 
cas, tanto respecto de las modificaciones unilaterales introducidas por la Administración, en su calidad de contraparte contractual, como aquellas que se sustentan en la dictación de normas generales emitidos por otros órganos del Estado -como el poder legislativo o el poder ejecutivo en el ejercicio de su potestad reglamentaria- que desvirtúan el estatuto jurídico inicial de derechos y obligaciones, así como los cambios contractuales derivados de hechos ajenos a la voluntad de las partes, imprevisibles e irresistibles que vuelven el cumplimiento de las obligaciones contractuales excesivamente oneroso.

Planteamos como interrogante de este trabajo, la hipótesis si en el Derecho administrativo, y específicamente, en el Derecho chileno se puede sustentar en términos absolutos que los contratos administrativos se encuentra sometidos integramente al principio pacta sunt servanda, que propugna que todo contrato es una ley para las partes y no admite modificaciones unilaterales de ninguna especie, asumiendo que toda alteración debe provenir del acuerdo de las partes o del mandato del legislador. $\mathrm{O}$ si por el contrario, atendida la finalidad de interés público que informa a los contratos administrativos, nuestro ordenamiento jurídico tolera la modificación unilateral directa o indirecta como una vía válida para satisfacer las necesidades públicas en un momento determinado. Y si esas modificaciones al contrato se encuentran sujetas a la mantención permanente del equilibrio económico financiero de los contratos administrativos, con la debida indemnización, en virtud del principio de igualdad antes las cargas públicas.

Para una adecuada respuesta de las interrogantes planteadas comenzaremos exponiendo el régimen potestativo exorbitante en los contratos administrativos, para luego analizar las condiciones y requisitos que buscan mantener el equilibrio económico contractual.

\section{RÉGIMEN POTESTATIVO EXORBITANTE EN LA CONTRATACIÓN ADMINISTRATIVA}

Una de las características que se advierte en el Derecho administrativo es la búsqueda permanente de un adecuado equilibrio entre potestades públicas y los derechos de los particulares en las distintas actividades donde interviene la Administración del Estado. Es un hecho que el legislador inviste a los órganos públicos de poderes jurídicos de imposición unilateral, cuya finalidad no es otra, que la satisfacción de necesidades públicas concretas en un momento determinado.

La presencia de esas potestades públicas condicionan las relaciones jurídicas entre el Estado y los particulares, sea que éstas se presente en 
forma unilateral o bilateral. Precisamente, en el campo de la actividad jurídica unilateral, el acto administrativo se encuentra revestido por una serie de caracteres que confirman la hegemonía del poder unilateral de Estado sobre los particulares. En efecto, el artículo $3^{\circ}$ de la Ley $\mathrm{N}^{\circ} 19.880$, de 2003, que Establece Bases de los Procedimientos Administrativos que rigen los Actos de los Órganos de la Administración del Estado, dispone que los actos administrativos gozan de la presunción de legalidad, imperio, exigibilidad, habilitando a la Administración del Estado a ejecutar de oficio lo resuelto por los órganos públicos, entregándole el legislador un verdadero privilegio de autotutela ejecutiva ${ }^{1}$.

Esta supra posición de la Administración, adquiere mayor intensidad en el acto administrativo terminal, donde el legislador le entrega a los órganos administrativos sendas potestades de retiro que le permiten volver sobre sus actuaciones por razones de legalidad en el caso de la invalidación (art. 53), o por razones de mérito, oportunidad o conveniencia en el caso de revocación (art. 61), generando una descompensación de las relaciones jurídicas en su favor o en contra de los derechos de los particulares que se relacionan con ella.

La actuación bilateral de la Administración no es ajena a la presencia de un régimen potestativo estatal intenso justificado en razones de bien común. En la actividad contractual el legislador inviste a los órganos del Estado de prerrogativas que adquieren un grado de exorbitancia relevante, no obstante la presencia de los principios lex inter partes y pacta sunt servan$d a$ ampliamente reconocidos por la doctrina ${ }^{2}$ y jurisprudencia ${ }^{3}$. En efecto, en la contratación pública, la presencia de potestades exorbitantes es uno de los elementos de los que se sirve la doctrina para definir la existencia misma de los contratos administrativos ${ }^{4}$, y elevar a la Administración del Estado a una posición de privilegio unilateral, que le permite modificar o extinguir las relaciones contractuales en aras de una adecuada gestión de las necesidades públicas, estas últimas - necesidades publicas- las que permiten sustentar la configuración del contrato administrativo como una categoría jurídica distinta de los contratos privados 5 .

${ }^{1}$ Ferrada Bórquez, Juan Carlos, Las potestades y privilegios de la Administración Pública en el régimen administrativo chileno, en Revista de Derecho (Valdivia) 20 (2007), 2, p. 83.

${ }^{2}$ Moraga Klenner, Claudio, Contratación administrativa (Santiago, Editorial Jurídica de Chile, 2007), p. 202.

${ }^{3}$ CS, 22 de enero de 2013, Rol No 6988-2012.

${ }^{4}$ De laubádere, André, Traité des contrats administratifs (2a edición, Paris, LGDJ, 1984), p. 40.

${ }^{5}$ Oelckers Camus, Osvaldo, Los principios informadores de la contratación 
Tradicionalmente, el legislador -en el campo de la contratación pública- inviste a la Administración del Estado de potestades de variación conforme a la combinación de criterios de gradualidad y de causalidad. En este contexto, en primer lugar, se encuentran la potestad de dirección del contrato y la potestad variandi, que permite a la Administración-cocontratante dirigir y modificar unilateral el contrato -ius variandi-sin necesidad que las partes o un juez resuelvan su procedencia, por exigencias del interes público. En segundo lugar, la intensidad y la causalidad aumentan frente a la presencia del factum principi, que ampara la modificación indirecta de los contratos administrativos debido a la publicación o dictación de una norma legal o reglamentaria ajena a la relación contractual que altera el objeto del contrato. Finalmente, la intensidad bordea los límites del caso fortuito y la fuerza mayor con la teoría de la imprevisión, cuya presencia altera el contrato haciéndolo excivamente oneroso frente al encarecimiento desmedido de las obligaciones inicialmente contraídas.

\section{Potestad de variación o ius variandi}

Una primera forma de alterar el contenido original de los contratos administrativos se relaciona con la potestad reconocida a los órganos de la Administración del Estado de modificar unilateralmente su contenido con la finalidad de alcanzar una adecuada satisfacción de las necesidades públicas. Es el interés público presente en todo contrato administrativo que justifica la presencia de la potestad que permite modificar su contenido y condiciones en razón de la satisfacción de necesidades concretas.

Materialmente para que opere la potestad variandi como causal generadora de desequilibrio económico de los contratos administrativos deben cumplirse los siguientes presupuestos fácticos: a) debe producirse por hechos o condiciones que no puedan ser imputable a la parte que reclama el restablecimiento, por ser extraño a ella y por tratarse de un hecho proveniente de la otra parte contratante ${ }^{6} ; b$ ) debe ser consecuencia de hechos o acontecimientos posteriores a la presentación de la propuesta o celebración del contrato; $c$ ) debe ser causada por un álea anormal de

administrativa, en Revista de Derecho de la Pontificia Universidad Católica de Valparaiso 7 (1983), pp. 148-149.

${ }^{6}$ Así en el Dictamen 36.796, de 2017, la Contraloría señaló que: “(...) en el contexto descrito, y considerando que el referido aumento de plazo fue otorgado con motivo del retraso producido por las circunstancias antes indicadas, las que según lo señalado por el ITO no serian atribuibles a un incumplimiento de la contratista y habrian impactado el programa de trabajo, es dable concluir que corresponde la indemnización recabada". 
carácter administrativo o ejercicio de una portestad; y d) debe afectar la economía del contrato de forma grave y anormal'.

Aclarado los presupuestos facticos que permiten el ejercicio de la potestad variandi, el principio pacta sunt servanda exige que la potestad variandi sólo sea procedente dentro de un marco inspirado por el principio de juridicidad, no admitiendo que los órganos estatales alteren los contratos válidamente celebrado sin sujeción a ninguna formalidad o acudiendo a potestades implícitas reñidas con la seguridad jurídica. En efecto, para el válido ejercicio de la potestad variandi deben concurrir las siguientes condiciones:

a) Ejercicio legal de una potestad contractual de la Administración.- Este primer requisito se refiere a que la potestad variandi, se encuentra sujeta integramente al principio de juridicidad, no obstante se acuda al término ius variandi, jurídicamente no es más que la manifestación de un poder jurídico exorbitante atribuido por el legislador en marco de un contrato administrativo cuyo objeto es modificar las condiciones contractuales para dar satisfacción a las necesidades públicas.

De esta forma, no es correcto es hablar de ius, como sinónimo de derecho subjetivo para referirse a la modificación unilateral del contrato, sino que lo propio es hablar de potestas, de la cual el órgano se encuentra investido no por la relación jurídica del contrato, sino por la ley. Esto queda reflejado en que el derecho subjetivo se agota normalmente con su ejercicio, mientras que la potestad, en cambio, es inagotable, en el sentido que el ejercicio de ella no se consume ni se disminuye ${ }^{8}$.

Materialmente, la alteración del equilibrio económico del contrato administrativo proviene del ejercicio de una potestad atribuida por el legislador, en algunos casos de manera específica, como ocurre en el artículo 105 del DS No 75 de 2004, que contiene el Reglamento del Contrato de Obra Pública, el cual faculta a la autoridad para ordenar dentro de los límites permitidos y con el fin de llevar a un mejor término la obra contratada, la modificación de obras previstas, la ejecución de obras nuevas o extraordinarias, o el empleo de materiales no considerados. O en forma general remitiendo la regulación de su ejercicio a las bases de licitación, como en el caso del artículo 13 de la Ley $\mathrm{N}^{\circ} 19.886$, de 2003, respecto de los contratos de suministro y prestación de servicio, que consagra que

${ }^{7}$ GonZález-varas IbáÑez, Santiago, El contrato administrativo (Madrid, Civitas, 2003), p. 274.

${ }^{8}$ Ariño, Gaspar, Teoría del equivalente económico en los contratos administrativos (Madrid, Instituto de Estudios Administrativos, 1968), p. 226. 
los contratos administrativos regulados por esta ley podrán modificarse por exigirlo el interés público o la seguridad nacional o las demás causales establecidas en las bases de licitación.

Cabe aclarar que el ejercicio del ius variandi se concreta en la dictación de un acto administrativo emanado de la Administración del Estado como contraparte contractual y; que goza de todos las prerrogativas reconocidas en el artículo 3 de la Ley No 19.880, presunción de legalidad, imperatividad, exigibilidad y ejecución de oficio. No obstante para el correcto ejercicio de la potestad variandi, el acto administrativo debe ser válido, exento de vicios esenciales, trascendentes y perjudiciales que impidan su cumplimiento y ejecución, bajo sanción de nulidad. Ahora, si el acto administrativo adolece de vicios menores, convalidables, consideramos que el particular contratista igualmente debe cumplir su contenido por exigencia del interés general, haciendo expresa reserva del derecho a la adecuada compensación frente a la ruptura del equilibrio económico financiero del contrato.

Un segundo requisito para que opere la potestad variandi es esencial que el ejercicio potestativo del órgano contratante ocurra con posterioridad a la época de perfeccionamiento del contrato, esto es, luego de la adjudicación. El ejercicio exorbitante debe ocurrir durante la ejecución del contrato, no siendo razonable que se invoque durante la etapa de licitación o una vez que el contrato ya ha sido terminado y liquidado, porque en ambos casos no existe una relación contractual vigente.

Durante, la etapa precontractual no podría afirmar que existe un verdadero contrato administrativo, ostentando los licitantes una expectativa legítima, sujeta a protección jurídica, dependiendo del grado de avance de la licitación, así como de la infracción normativa en que incurra la Administración del Estado?.

Respecto de la etapa de terminación y liquidación del contrato, a nuestro juicio es ineficaz invocar la mantención del equilibrio económico del contrato, por cuanto, si bien pueden existir algunos indicios de relación contractual, la liquidación administrativa que realiza la Administración del Estado tiene por objeto preciso finiquitar los derechos y obligaciones entre las partes, evitando enriquecimientos ilícitos de cualquiera de las partes.

b) La alteración debe constituir un álea extraordinario.- Este requisito exige que el acto que altere las condiciones contractuales constituya un álea extraordinario dentro del contrato. Ahora bien, puede resultar contradictorio que los contratantes invoquen la aplicación del equilibrio económico

${ }^{9} \mathrm{CS}, 30$ de septiembre de 2015, Rol N²795-2015. 
financiero del contrato, si saben o debieron saber que la Administración puede ejercer potestades para alterar las condiciones del contrato cuando el interés general lo exiga. En otras palabras existe un cierto un grado de riesgo que el contratista asume al contratar con la Administración como ente potestativo garante del interés general. Cuando se supera ese riesgo estamos frente a un álea extraordinario.

El álea extraordinario de la medida administrativa para la aplicación de la potestad variandi debe ser entendido no como la imposibilidad de prever que la Administración no hará uso de su potestad modificatoria cuando razones de interés público lo exijan, sino como el cambio imprevisible en las circunstancias fácticas y económicas en que se desarrolla el contrato, que obliga a la Administración a modificarlo para satisfacer el interés general ${ }^{10}$. Por tanto, el conocimiento de la potestad variandi dentro del contrato no es una asunción de responsabilidad, puesto que, no obstante el conocimiento específico del privado de las postestades públicas, esto no le impide al contratista reclamar de la alteración de álea extraordinario del contrato, si la alteración del contrato era imprevisible para cualquier contratista en la misma posición jurídica.

c) Agravamiento de la economía del contrato.- El deber de indemnizar que recae sobre el Estado cuando ejerce la potestad variandi, se activa en la medida que el contratante particular sufra un daño o perjuicio a consecuencia del cambio unilateral en las circunstancias del contrato. Es indispensable que exista un daño concreto manifestado en un desajuste de las condiciones iniciales del contrato, que haga más gravoso el cumplimiento del objeto contractual.

Un tema crucial para determinar el sentido y alcance de la extensión del deber de reparar o reequilibrar el contrato, consiste en precisar la intensidad del perjuicio sufrido por el contratista que genera el deber de indemnizar. En este contexto, nos preguntamos si ¿Es reparable todo daño o se admite que hay grado de desequilibrio contractual que deben quedar entregados al riesgo y ventura del contratista?

Una parte importante de la doctrina estima que para la aplicación del ius variandi y el deber de indemnizar: "(...) no es indispensable probar que el contrato haya pasado a ser excesivamente gravoso. Basta que el cocontratante de la Administración que resulta perjudicado acredite que existió un daño cualquiera, no importa su monto o extensión"11.

${ }^{10}$ ARIÑo, cit. (n. 8), p. 735.

${ }^{11}$ Rodríguez, Libardo, El equilibrio económico en los contratos administrativos (Bogotá, Temis, 2012), p. 55. 
Esta afirmación se puede sustentar en dos postulados relevantes. El primero se encuentra estrechamente relacionado con los fundamentos constitucionales del principio de responsabilidad y el deber estatal de respetar la igualdad ante las cargas públicas, que habilita a todo aquel que haya sufrido una lesión por el Estado o sus organismos reclamar indemnización de perjuicio ante los Tribunales de Justicia. Máxime cuando la alteración de las obligaciones y cargas impuestas en el contrato es causante de una lesión que deriva en un sacrificio especial que cede en beneficio de toda la comunidad.

Un segundo postulado que sustenta la prescindencia de acreditar un perjuicio relevante se relaciona con la alteración contractual misma, por cuanto, la potestad variandi resulta imputable a una parte determinada del contrato sin injerencia del contratante privado. De esta forma, resulta perjudicial para este último que el Estado determine unilateralmente y en forma preventiva que perjuicios serán indemnizables y cuáles no, sin la debida intervención de un tercero independiente e imparcial.

d) Extensión y límites del ius variandi: Intento de armonización ${ }^{12}$.- Aclarados los requisitos y condiciones para que opere la potestad variandi, la trascendencia de su finalidad lleva afirmar a parte de la doctrina que dicha potestad aparentemente no tendría límites en cuanto a su intensidad y extensión, por cuanto el interés general debe prevalecer en todo caso y bajo cualquier circunstancia. Afirma García de Enterría que obligar a la comunidad a soportar una carretera, un puerto o un embalse mal planteado ab initio, inútiles o ineficaces desde su misma concepción, por simple respeto a la lex contractus, no tendría sentido. De este modo, al servicio del interés público y de sus concretas e insoslayables exigencias, el ius variandi de la Administración contratante es ilimitado en extensión o intensidad, ya que el interés público prima sobre cualquier otra consideración ${ }^{13}$.

No obstante, lo trascendental de las necesidades públicas y la unilateralidad e imperatividad con que se impone el ius variandi, otra parte de la doctrina estima que es preciso que exista una adecuada armonización

${ }^{12}$ Mediante el Dictamen 85.856, de 2016, la Contraloría ha señalado que: "Por otra parte, cabe consignar que la jurisprudencia administrativa de este Ente de Control ha sostenido -v.gr., en sus dictámenes $N^{\circ}$ s. 19.982, de 2012, y 77.378, de 2014-que son requisitos para que proceda la indemnización por mayores gastos generales que la modificación del programa de trabajo sea dispuesta por la Administración en atención a circunstancias especiales, que dicha modificación genere un aumento de plazo y que esta ampliación no obedezca a otras causales previstas en el reglamento".

${ }^{13}$ García de Enterría, Eduardo - Fernández, Tomás Ramón, Curso de Derecho Administrativo (15ª edición, Cizur Menor, Civitas, 2011), I, p. 705. 
entre el ius variandi y el principio pacta sunt servanda, dado que el ius variandi se encuentra sujeto al principio de legalidad ${ }^{14}$, a la obligación de no afectar al contrato en su esencia ${ }^{15}$, o simplemente a la obligación de acreditar la existencia de un interés público que justifique la invocación de esta prerrogativa administrativa exorbitante para vulnerar el principio pacta sunt servanda ${ }^{16}$.

En efecto, la potestad variandi se encuentra sujeta a límites a fin de no desnaturalizar la relación contractual y que no exista una situación de enriquecimiento sin causa a favor del Estado al implementar un cambio que cede en beneficio de la comunidad pero a expensas del particular contratante. Ariño propone como límite de la potestad variandi, el interés general y la ecuación económica financiera del contrato, pues entiende que la potestad variandi representa el contrapunto del principio de mantenimiento del equivalente económico ${ }^{17}$.

Por su parte, Granillo propone que la potestad variandi no puede implicar la posibilidad de modificar todas y cada una de las cláusulas del contrato, ni es sinónimo de la existencia de una potestad discrecional y arbitraria que someta todo el contrato a la voluntad de una de las partes. Es el interés general el que condiciona que la potestad variandi no se transforme en arbitraria o que encierre una desviación de fin. En efecto, la facultad de la Administración de alterar el contrato no puede destruir la sustancia del contrato, llegando a configurar por vía administrativa un contrato diferente sobre el cual el contratista no ha prestado su consentimiento. Asimismo, la potestad variandi se encuentra limitada por aquellas cláusulas contractuales que establecen y hacer efectiva la ecuación económica del contrato, que debe mantenerse inalterable ${ }^{18}$.

Para determinar el grado de alteración contractual, hay que tomar como criterio el nivel de intensidad con que en el caso concreto concurre la potestad variandi sobre las cláusulas contractuales. En efecto, la modificación contractual tolerada por el principio pacta sunt servanda en un

${ }^{14}$ Coviello, Pedro, El contrato administrativo: ¿lex inter partes o ius variandi?, en Revista de Derecho de la Universidad Católica del Perú 66 (2011), p. 185.

${ }^{15}$ Marienhoff, Miguel, Tratado de Derecho Administrativo (4 a edición, Buenos Aires, Abeledo-Perrot, 1994), III-A, p. 395.

${ }^{16}$ De laubádere, cit. (n. 4), pp. 403-405.

${ }^{17}$ Flores Rivas, Juan Carlos, Revisión de contratos administrativos. El adecuado equilibrio entre potestades exorbitantes y los derechos contractuales, en LAGUNA DE PAZ, José Carlos - Sanz Rubiales, Iñigo - De los Mozos y Touya, Isabel María (coords.), Derecho Administrativo e integración europea. Estudios en Homenaje al profesor José Luis Martínez López-Muñiz (Madrid, Editorial Reus, 2017), p. 1015.

${ }^{18}$ Granillo Ocampo, Raúl Enrique, Distribución de riesgos en la contratación administrativa (Buenos Aires, Editorial Astrea, 1990), p. 92. 
contrato administrativo es aquella que solo busca modificar el contrato en sus aspectos accidentales, inocuos respecto de los elementos esenciales y definitorios del contrato, v.gr., aumentos de obras o nuevas obras hasta un determinado porcentaje $\mathrm{e}^{19}$. Lo que no tolera la fuerza vinculante de los contratos públicos es que la potestad variandi degenere en una herramienta de autotutela contractual que relativice al máximo el principio pacta sunt servanda ${ }^{20}$.

En efecto, el ejercicio del ius variandi exige una cuidadosa y fundada apreciación de los antecedentes de hecho o de derecho que lo hacen necesario o conveniente, puesto que se alteran las condiciones iniciales bajo las cuales se ofertó y adjudicó el contrato en cuestión, afectando los presupuestos del servicio público recargándolo de costos que no fueron previstos al momento de perfeccionarse el contrato ${ }^{21}$. Esta modificación unilateral del contrato hace nacer -en palabras de la Contraloría General de la República- derechos indemnizatorios o compensatorios en favor del contratante privado para restablecer cualquier equilibrio económico perdido con motivo del cambio de condiciones básicas de la contratación ${ }^{22}$.

\section{Hecho del principe o Factum principi}

Otro factor que puede alterar la estabilidad de los contratos administrativos, es el denominado hecho del príncipe o factum principis. El factum principis es aquel álea administrativo que resulta del ejercicio lícito de prerrogativas públicas generales, de un órgano de la Administración del Estado distinta de aquella que ha contratado o del poder legislativo, que conlleva un cambio en las condiciones originales del contrato, haciéndolo más gravoso para el contratante privado ${ }^{23}$.

El hecho del príncipe, se manifiesta cuando el poder público -el príncipe- agrava por un acto que emana de él, las condiciones de ejecución del contrato estando obligada a indemnizar al cocontratante. Santamaría Pastor, señala que se incurre en el hecho del príncipe cuando la adopción, por parte del mismo órgano u otro órgano del mismo ente público, de

${ }^{19}$ Un claro ejemplo es el artículo 102 del DS No 75 de 2004, del Ministerio de Obras Públicas sobre contrato de obras públicas, que consagra que "El Ministerio podrá, además, aumentar en los contratos a serie de precios unitarios las cantidades de obras hasta en un $30 \%$ de cada partida del presupuesto, en cuyo caso el contratista tendrá derecho a su pago, a los precios unitarios convenidos en el contrato, y a un aumento del plazo proporcional al aumento que haya tenido el contrato inicial".

${ }^{20}$ Coviello, cit. (n. 14), p. 187.

${ }^{21}$ Moraga, cit. (n. 2), p. 227.

${ }^{22}$ Dictamen 12.334, de 2002.

${ }^{23}$ Moraga, cit. (n. 2), p. 211. 
una medida de cualquier tipo, que sin referirse específicamente al contrato produce una alteración de sus términos, determinando una mayor onerosidad, una dificultad adicional para su cumplimiento generadora de gastos, o su pura y simple imposibilidad ${ }^{24}$.

Sin embargo, el hecho del príncipe supone que el contrato administrativo sufre una alteración producto de un hecho, o principalmente un acto proveniente del Estado, pero no en calidad de contratante contractual, se trata de decisiones imputables a la Administración Públicas no dirigidas de forma explícita al contrato, pero que alteran sus presupuestos económicos y/o financiero. La causa o finalidad de la alteración del equilibrio económico no tiene origen ni por objeto el contrato ${ }^{25}$.

En un sentido estricto, el hecho del príncipe designa actos provenientes de la autoridad pública contratante, que sin tener por objeto el contrato, generan efectos sobre el mismo en cuanto a las condiciones de su ejecución. De Laubàdere, entiende que en términos restringidos: "El hecho del príncipe es una medida tomada por la autoridad contratante que afecta las condiciones de ejecución del contrato. Pero, como medida tomada por la Administración contratante, el hecho del príncipe parece duplicarse. La administración contratante puede, en primer lugar, tomar una medida que tiene por objeto directo, y en consecuencia, al mismo tiempo por efecto, modificar las condiciones de ejecución del contrato. En segundo lugar, la Administración puede tomar una medida que si bien no tiene por objeto propio la ejecución del contrato, tiene un efecto sobre esta ejecución, (...) podríamos reservar para la segunda hipótesis la expresión hecho del príncipe"26.

Una vez aplicada la teoría del hecho del príncipe, genera consecuencias específicas en la relación contractual afectada por el acto de autoridad pública, que justifica la revisión y compensación del contratista afectado por esta carga pública desigual que cede en beneficio de la comunidad en general.

En nuestro sistema jurídico, el legislador se ha hecho cargo de esta situación, en el artículo 19 del DS No 900, de 1996, del Ministerio de Obras Públicas que contiene la Ley de Concesiones de Obra Pública, regulando los mecanismos compensatorios ante la presencia de actos sobrevinientes de la autoridad dotada con potestades públicas, exigiendo el cumplimiento copulativo de los siguientes requisitos: (i) que el acto se produzca con posterioridad a la adjudicación del contrato; (ii) que el acto

${ }^{24}$ Santamaría Pastor, Juan Alfonso, Principios de Derecho Administrativo (3a edición, Madrid, Editorial Centro de Estudios Ramón Areces, 2002), II, p. 231.

${ }^{25}$ AriÑo, cit. (n. 8), p. 736.

${ }^{26}$ De laubádere, cit. (n. 4), p. 1293. 
no haya podido ser previsto al tiempo de su adjudicación por las partes; (iii) que el acto no constituya una norma legal o administrativa dictada con efectos generales que exceda el ámbito de la industria de la concesión; y (iv) que el acto altere significativamente el régimen económico del contrato.

Una primera aproximación a los requisitos se relaciona con la previsibilidad del acto modificador del contrato al tiempo de la adjudicación del mismo. La medida administrativa que perturba el contrato no debe ser normalmente previsible, esto es, una carga sobre alguna de las partes contratantes que es ajena al tráfico jurídico normal, por cuanto se trata de hechos que exceden cualquier cálculo o previsión que el contratante perjudicado haya podido hacer al momento de estructurar su negocio ${ }^{27}$.

Conviene aclarar que la medida administrativa perturbadora del contrato puede ser una manifestación de la potestad normativa, un acto administrativo particular o general, o una norma legal proveniente del Congreso Nacional, que en principio puede provenir tanto del poder ejecutivo como el poder legislativo. No obstante, la previsibilidad del acto normativo se encuentra restringida por el artículo 19 exige que el acto perturbador sea una norma legal o administrativa general que exceda el ámbito de la industria.

Sin embargo, para que esta norma produzca sentido es preciso contextualizar, que al igual que en el caso de la potestad variandi, la previsibilidad no se encuentra relacionada con la evidencia que en todo contrato administrativo los órganos públicos se encuentran investidos de potestades exorbitantes, sino cómo el contenido del ejercicio potestativo afecta el equilibrio económico financiero del contrato administrativo. En efecto, todo contratista conoce antes de la adjudicación del contrato que la Administración puede y debe -ante necesidades públicas concretas- ejercer potestades con el objetivo de satisfacer el interés público ínsito en el contrato administrativo; cuestión distinta es conocer en forma anticipada el contenido, grado e intensidad de la medida administrativa consecuencia del ejercicio de la potestad.

Una segunda aproximación, a los requisitos exigidos por el artículo 19 del DS No 900, para la operatividad del hecho del príncipe es la limitación del acto normativo solo a las normas legales o administrativas de

${ }^{27}$ Marienhoff, cit. (n. 15), p. 761. Respecto a la imprevisibilidad, el Panel Técnico de Concesiones, creado por la Ley $\mathrm{N}^{\circ} 20.410$, de 2010, a propósito de la modificación del Plano Regulador de Iquique ha dispuesto que la imprevisibilidad debe ser razonable y tomar en consideración los plazos, procedimientos e información administrativa disponible para calificar como imprevisible la modificación de un plano regulador. Discrepancia, 17 de octubre de 2016, D07-2016-3, disponible [en línea]: www.paneldeconcesiones.cl. 
efectos generales o particulares circunscritas al ámbito de la industria de la concesión.

Ahora bien, como se puede apreciar para que el contratista afectado pueda invocar el hecho del príncipe, el artículo 19 regula una previsibilidad restringida o moderada que impide que el contratista pueda invocar cualquier innovación legislativa como sustento de una pretensión indemnizatoria. Solo las innovaciones normativas atingentes a la industria de la concesión sirven de título para solicitar la mantención del equilibrio económico financiero del contrato administrativo.

Consideramos que la configuración normativa de este requisito potencialmente puede generar indefensión del contratista que reclama una alteración normativa imprevisible del contrato administrativo, por cuanto limita la causa de la alteración solo a normas legales o administrativas generales o particulares propias de la industria de la concesión. Sobre este tópico debemos hacer dos prevenciones.

Respecto de la industria de la concesión, estimamos que no se agota solo a la concesión de obras públicas fiscales, sino que la Ley de Concesiones -DS $\mathrm{N}^{\circ} 900$, de 1996- ha sido una norma prolífica que ha servido de sustento a las nuevas concesiones, como las concesiones carcelarias, hospitales y embalses. Adicionalmente, la Ley de Concesiones ha servido para que aquellos servicios públicos sin competencias constructivas, acudiendo al artículo 16 de la Ley $\mathrm{N}^{\circ} 18.091$, puedan celebrar convenios administrativos para concesionar servicios ajenos a la Ley de Concesiones ${ }^{28}$, lo cual puede extender el ámbito de la industria de la concesión a otras variables v. gr., seguridad, médicas.

A nuestro parecer, la norma resulta excesivamente restringida para el contratista porque al parecer el legislador presume que solo las normas legales o administrativas relacionadas con el ámbito de la industria de la concesión, excluyendo la influencia de normas tributarias, aduaneras, laborales o financieras que perfectamente pueden alterar algunas de las condiciones previstas por el contratista al momento de presentar su oferta y celebrar el contrato.

En cuanto a la operación del factum principi, una primera aproxima-

${ }^{28}$ Lara, José Luis - García-Huidobro, Luis Eugenio, Sobre el régimen concesional chileno: ¿podemos hablar de un modelo de concesión?, en Sото KLoss, Eduardo (coord.), Administración y derecho: homenaje a los 125 años de la Facultad de Derecho de la Pontificia Universidad Católica de Chile (Santiago, LegalPublishing, 2014), pp. 89-165. Vid., Loo GutiérRez, Martín, La distribución de los riesgos en el contrato de concesión de obra pública, en Bermúdez Soto, Jorge (ed.), Perspectivas para la modernización del derecho de la contratación administrativa (Valparaíso, Ediciones Universitarias de Valparaíso, 2016), pp. 193-208. 
ción es considerar que su ocurrencia genera un caso de responsabilidad contractual del Estado por infracción a la igual repartición de las cargas públicas. Dromi sostiene que la cláusula que incorpora el hecho del príncipe dentro del marco del contrato administrativo es de orden público, y por lo tanto irrenunciable ${ }^{29}$.

Por su parte, Marienhoff, afirma que: “(...) sería nula la cláusula en cuyo mérito el contratante renuncie, o aparezca renunciando, de manera general, a reclamar indemnización por los perjuicios que le origine el hecho del príncipe. Trataríase de una cláusula de las llamadas ilegales"30.

Finalmente, en cuanto a la vigencia del contrato, está claro que la teoría del hecho del príncipe tiene por objetivo garantizar la equivalencia económica del contrato administrativo, con la finalidad que los servicios públicos se presten de manera regular y continua. Lo anterior, se traduce en que el contratante de la Administración, no obstante la onerosidad de la intervención administrativa, para obtener la adecuada indemnización de los perjuicios, es preciso que continúe prestando el servicio público, esto es, que a pesar de la onerosidad cumpla con el contrato administrativo hasta el punto que el supuesto de hecho del príncipe no implique una alteración de tal magnitud que suponga un caso de fuerza mayor que podría lugar a la resolución contractual ${ }^{31}$.

\section{Teoría de la imprevisión ${ }^{32}$}

Una tercera forma en que la estabilidad de los derechos y obligaciones de un contrato administrativo sufren alteraciones por hechos externos, es la denominada teoría de la imprevisión o excesiva onerosidad sobreviniente de las prestaciones. La teoría de la imprevisión tiene lugar en los contratos de tracto sucesivo y se sustenta en una alteración del álea económico del contrato administrativo, debido a hecho o situaciones anormales, extrañas a los contratantes, que alteran las condiciones económicas que se tuvieron presentes al momento de perfeccionarse la voluntad contractual.

Péquignot, ha formulado la teoría de la imprevisión bajo el siguiente

${ }^{29}$ Dromi, Roberto, Licitación Pública (4a edición, Buenos Aires, Ediciones Ciudad Argentina, 2010), p. 561.

${ }^{30}$ MarienhofF, cit. (n. 15), p. 772.

${ }^{31}$ Rodríguez, cit. (n. 11), p. 95.

${ }^{32}$ En el Dictamen 10.624, de 2006, la Contraloría señaló, que: "Además, cabe ponderar que aun cuando en el ámbito del Derecho Administrativo impera el principio de que en los pactos administrativos rige el elemento de riesgo o ventura, esto es, que el cocontratante de la Administración soporte el riesgo del cumplimiento de las obligaciones que impone la convención, tal principio no es absoluto, pues admite excepción en caso de que exista imprevisión, caso fortuito o fuerza mayor, dando derecho al obligado para que ellos sean soportados por quien hace el encargo". 
planteamiento: "Cuando circunstancias imprevistas al momento de la celebración del contrato generan un trastorno grave en su economía y la gravedad de la alteración así provocada, sin hacer imposible la ejecución del contrato, la hace difícil y onerosa, más allá de lo que las partes habían podido prever razonablemente, y cuando el déficit de la operación sobrepasa los límites del álea normal a la carga de todo contratista, adoptando un carácter anormal y excepcional, el contratante de la administración tiene el derecho a pedir a ésta que venga en su ayuda, que comparta con él el álea extraordinario y que reconozca una indemnización calculada en función del déficit soportado y de todas las circunstancias del caso" ${ }^{33}$.

En este sentido, la teoría de la imprevisión se configura como uno de los eventos que puede presentar una ruptura en el equilibrio económico del contrato administrativo, se trata de una de las causales de rompimiento de la ecuación contractual que se presenta por situaciones imprevistas, exógenas a las partes y posteriores a la celebración del contrato, que generan una alteración anormal en la economía del mismo, haciéndolo más gravoso ${ }^{34}$, mas no imposible de cumplir.

Para invocar la teoría de la imprevisión, la doctrina administrativa francesa clásica ha configurado cuatro reglas para que sea procedente reclamar de la Administración la asistencia económica que reestablezca el equilibrio económico del contrato ante un evento de excesiva onerosidad sobreviniente.

Una primera regla se relaciona con la vigencia del contrato afectado por la excesiva onerosidad sobreviniente, específicamente que el cocontratante de la Administración no puede oponer este hecho extraordinario como fundamento para incumplir el contrato administrativo. El particular tiene el deber de cumplir con las prestaciones pactadas, es decir, ante la ocurrencia de un hecho excepcional e imprevisible debe seguir cumpliendo con las obligaciones del contrato, máxime si el objeto del contrato envuelve la prestación de un servicio público que exige una prestación continua e ininterrumpida.

Una segunda regla relacionada directamente con la anterior, establece que la obligación de cumplimiento del contrantante solo desaparece o se extingue, cuando producto del hecho excepcional e imprevisible deviene en imposible de cumplir, cuando se configura una hipótesis de caso fortuito o fuerza mayor. La imprevisibilidad, dogmáticamente no ostenta la impronta suficiente para arribar a supuestos de caso fortuito o fuerza

${ }^{33}$ Peguignot, Georges, Théorie Générale du Contrat Administratif (París, A. Pedone, 1944), p. 502.

${ }^{34}$ RodrígueZ, cit. (n. 11), p. 103. 
mayor, sino que, el contrato puede cumplirse en términos más gravosos, sin que desaparezcan los derechos y obligaciones inicialmente pactadas.

En tercer lugar, si el cocontratante como consecuencia del hecho excepcional e imprevisible no cumple con las obligaciones del contrato, la Administración queda habilitada para aplicar la caducidad o extinción unilateral del contrato. En este sentido, es relevante que el contratista, no obstante la existencia de un hecho imprevisible, se encuentra llano a cumplir con el contrato, para que pueda invocar en su favor los beneficios de la teoría de la imprevisión.

En cuarto lugar, sólo si el cocontratante cumple con las obligaciones y no interrumpe la prestación del servicio, tiene derecho a que la Administración participe de las pérdidas derivadas de la imprevisión ${ }^{35}$.

Ahora bien, la configuración de los requisitos de la teoría de la imprevisión es una materia que no solo ha sido revisada por el Derecho administrativo, sino que también el Derecho privado ha ahondado en la determinación de sus elementos. Así la doctrina civilista nacional ha resumido los requisitos para su procedencia en los siguientes: $i$ ) que se trate de contratos de tracto sucesivo o de cumplimiento diferido; ii) que por causas sobrevinientes imprevistas, imprevisibles y extraordinarias se altere de tal forma la equivalencia de las prestaciones que, sin llegar a constituir un obstáculo absoluto para el cumplimiento de la obligación; iii) que impongan a uno de los contratantes una excesiva onerosidad ${ }^{36} ; \mathrm{y}$ iv) que el cambio en las circunstancias no sea imputable a dolo o culpa del deudor ${ }^{37}$.

Desde la óptica del Derecho administrativo, la doctrina especializada ha detectado los siguientes requisitos que deben estar presentes para que pueda ser invocada la teoría de la imprevisión. En primer lugar, el hecho o acontecimiento que produce la alteración de las condiciones contractuales debe ser extraño e imprevisible a las partes. En segundo lugar, el hecho o acontecimiento que altere las condiciones contractuales debe ser posterior a la presentación de la propuesta o la celebración del contrato. En tercer lugar, el hecho o acontecimiento que altera las condiciones contractuales debe constituir un álea extraordinario. Y finalmente, el hecho o aconteci-

${ }^{35}$ Jéze, Gastón, Principios generales del Derecho Administrativo. Teoría general de los contratos de la Administración (Buenos Aires, Depalma, 1950), IV, p. 16.

${ }^{36}$ Dörr ZEger, Juan Carlos, Notas acerca de la teoría de la imprevisión, en Revista Chilena de Derecho 12 (1985), p. 264. Cfr., Peñailillo Arevalo, Daniel, La revisión judicial de obligaciones y contratos en la reforma del Código Civil (La lesión y la imprevisión), en Revista de Derecho. Universidad de Concepción 208 (2000), pp. 230-231.

${ }^{37}$ Corral Talciani, Hernán, Contratos y daños por incumplimiento (Santiago, Abeledo Perrot, 2010), p. 247. 
miento imprevisible debe hacer excesivamente oneroso el cumplimiento del contrato, esto es, de afectar gravemente el cumplimiento de las obligaciones contractuales no ha haciendo imposible su cumplimiento ${ }^{38}$.

a) Hecho o acontecimiento imprevisible a las partes ${ }^{39}$.- Este requisito se relaciona con el conocimiento razonable que asume el contratista o la Administración sobre los riesgos que pueden alterar el cumplimiento del contrato haciéndolo más oneroso. El hecho o acontecimiento que altera el equilibrio económico financiero del contrato debe ser ajeno a cualquiera de las partes del mismo, excluyendo todo comportamiento culposo o doloso de las partes para impactar el normal desarrollo del contrato ni debe provenir del ejercicio potestativo del Estado cocontratante - potestad variandi- o del Estado como ente legislativo o reglamentario, como en el caso del hecho del príncipe.

Es clave entender que la exigencia de este requisito supone que ninguno de los contratantes - particular y el Estado- hayan podido razonablemente prever la ocurrencia de un hecho extraordinario. Por lo tanto, dice relación con hechos que no fueron tomados en consideración al momento de celebrar el contrato, sin importar cuán diligente fuere el comportamiento contractual de los contratantes, no hubiesen podido ser previstos por cualquier otro contratante en su posición ${ }^{40}$.

La doctrina civil entiende que para determinar el grado de previsibilidad del hecho o acontecimiento excesivamente oneroso es necesario la utilización de un estándar o modelo de hombre medio razonable, no siendo necesario apuntar a las características personales del sujeto: “(...) sino realizarse de un modo objetivo, con referencia a un modelo que puede construirse sobre la base del hombre medio razonable de una comunidad jurídica, teniendo en cuenta las características más destacadas de litigante afectado (en educación, actividad, etc.)"¹ .

También resulta relevante para que pueda tener aplicación práctica la teoría de la imprevisión que la parte afectada por la excesiva onerosidad de su obligación, no se haya constituido en mora, es decir, que no se encuentre en retardo en el cumplimiento de sus obligaciones. Recordemos

${ }^{38}$ Rodríguez, cit. (n. 11), p. 118.

${ }^{39}$ La Contraloría en el Dictamen 31.163, de 2005, señaló que: "Asimismo en la especie no procede invocar la aplicación de la "teoría de la imprevisión", por cuanto la implementación de la aludida institución era una circunstancia conocida por todos los concursantes a la época de presentación de las propuestas, de tal forma que podían adoptar las medidas para precaver los efectos (...)".

${ }^{40}$ De laubadére, cit. (n. 4), p. 90.

${ }^{41}$ Corral, cit. (n. 38), p. 248. 
que el efecto principal de la mora es transferir las responsabilidades desde la parte diligente a aquella incumplidora. Así, el deudor que se encuentra en mora, se hace responsable del caso fortuito, es decir, de la imposibilidad absoluta en el cumplimiento. Lo anterior no es más que una consecuencia de la mora, por cuanto si ésta ostenta la capacidad para hacer responsable al deudor incluso del caso fortuito, con mayor razón será responsable de una imposibilidad relativa en el cumplimiento de la obligación.

b) Hecho o acontecimiento posterior a la celebración del contrato.- El hecho o acontecimiento perturbador del contrato que lo transforma en excesivamente oneroso debe ser posterior a la presentación de la propuesta o la celebración del contrato. Recordemos que la vida del contrato se extiende entre su adjudicación y terminación. El hecho imprevisible debe ocurrir durante la etapa de ejecución del contrato, después de haberse trabado la relación jurídica bilateral y antes que el contrato se termine $e^{42}$.

Cabe preguntarse sobre la posibilidad que el hecho o acontecimiento imprevisible ocurra durante la etapa de licitación y sus efectos se extiendan a la ejecución del contrato, en otras palabras ¿̇i el acontecimiento calificado de imprevisible se encuentra limitado a la etapa de ejecución contractual o se admite que un hecho extraño e imprevisible ocurra en la etapa de licitación, pero sus efectos se manifiesten en la ejecución contractual?

A nuestro juicio, consideramos que los hechos imprevisibles no se encuentran limitados en término estrictos a la etapa de ejecución, sino que podría perfectamente haber nacido durante la etapa de licitación el germen del hecho imprevisible, cuyas consecuencias se concretan en la etapa de ejecución contractual. Estimamos que un caso específico provendría de errores de información del proyecto entregado por el Estado o de actos derivados de variables que estimaban ajenas a la ejecución contractual por ser exógenas al rubro o industria.

c) El hecho o acontecimiento debe constituir un álea extraordinario.- Hemos señalado que lo imprevisible es aquello que no ha podido ser conocido con anterioridad por las partes del contrato. La falta de previsión se debe a la imposibilidad, quedando absolutamente descartada la falta de cuidado o diligencia. Frente a la teoría de la imprevisión, es importante determinar cuándo un acontecimiento se puede o no considerar imprevisible para las partes de la relación contractual. Esta determinación es una cuestión de hecho que queda sometida a la valoración de los jueces de fondo, por

\footnotetext{
${ }^{42}$ Marienhoff, cit. (n. 15), p. 787.
} 
lo que es fundamental establecer qué criterio es el que deben emplear en dicho cometido.

En sentido, Rodríguez afirma que la determinación de la imprevisibilidad del hecho alterador de las condiciones contractuales no puede hacerse en abstracto sino que deben ser siempre tenidas en cuenta las circunstancias específicas de cada caso concreto. De este modo, debe tratarse de una carga ajena al tráfico jurídico normal, que supera cualquier cálculo o previsión, siempre que no sean consecuencia de la impericia o del comportamiento negligente o culposo de la parte perjudicada ${ }^{43}$.

Este requisito también condiciona la temporalidad de la alteración de la economía del contrato, el acto perturbador no puede tener efectos definitivos, sino que debe ser transitorio, temporal y no permanente, al punto que no impida definitivamente la ejecución contractual ${ }^{44}$, sin caer en una hipótesis de caso fortuito que torne imposible el cumplimiento de las obligaciones del contrato.

d) Excesiva onerosidad en el cumplimiento del contrato.- Finalmente, este requisito es esencial para la configuración de la teoría de la imprevisión, porque no basta con la ocurrencia de un álea extraordinario que afecte en forma sobreviniente el contrato, sino que es preciso que se altere la economía contractual en término radicales, que las condiciones económicas inicialmente pactadas se vean impactadas haciendo el contrato más oneroso, o disminuyendo sustancialmente las potenciales utilidades previstas dentro de la ecuación económica del contrato. Es claro, que lo alterado debe ser la economía del contrato y no la economía del contratista individualmente considerado.

En el caso de contratos bilaterales onerosos conmutativos, teóricamente se puede sostener que la onerosidad excesiva, se concreta en que una de las prestaciones ha adquirido un valor desmesurado en relación con la otra, que ha disminuido notablemente su valor o ha perdido legítimamente todo interés para la parte afectada por el hecho imprevisible ${ }^{45}$.

Momberg, sistematiza la excesiva onerosidad sobreviniente en las siguientes situaciones: $i$ ) el cumplimiento de la obligación ha devenido en excesivamente oneroso, esto es, los costos de la ejecución de la prestación han aumentado de manera considerable en comparación a los previstos a la fecha de celebración del contrato; ii) la contraprestación se ha desvalorizado ostensiblemente, ya sea porque la moneda en la cual se ha fijado

\footnotetext{
${ }^{43}$ Rodríguez, cit. (n. 11), p. 119.

${ }^{44}$ JÈZE, cit. (n. 36), p. 20.

${ }^{45}$ Momberg Uribe, Rodrigo, Teoría de la imprevisión: la necesidad de su regulación legal en Chile, en Revista Chilena de Derecho Privado 15 (2010), p. 50.
} 
el precio ha perdido valor adquisitivo o porque el precio de mercado del bien, objeto del contrato, ha disminuido considerablemente; y iii) el cumplimiento de la contraprestación ya no satisface el fin previsto por las partes al momento de contratar, es decir, la ejecución del contrato en sí ha perdido sentido para el acreedor ${ }^{46}$.

Si bien, queda a criterio del juez la determinación del quantum de la excesiva onerosidad sobreviniente, se suele agregar por la doctrina civil que al detectar un caso de excesiva onerosidad, la parte que invoca la teoría de la imprevisión debe haber sufrido una perturbación radical en el cumplimiento de sus obligaciones contractuales, mientras que la otra parte no debe haberse enriquecido a costa de la imprevisión ${ }^{47}$.

\section{MANTENCIÓN DEL ADECUADO EQUILIBRIO ECONÓMICO:}

DEBER ESTATAL DE INDEMNIZAR

El ejercicio de la potestad variandi, la dictación de normas legales o administrativas -factum principi- o la ocurrencia inesperada de acontecimientos imprevisibles a las partes, que afectan el normal desarrollo y cumplimiento de las obligaciones del contrato administrativo, haciendo excesivamente oneroso, ajeno a toda proyección considerada al tiempo de la adjudicación del contrato, deben ser compensado o indemnizados para restablecer el equilibrio contractual.

¿Quién debe asumir el exceso económico-financiero que implica la alteración contractual por un acto o hecho sobreviniente? ¿Es lícito invocar el riesgo y ventura como fundamento para generar una situación de irresponsabilidad estatal?

Sobre el particular, la doctrina ha entendido que el hecho de considerar al contratista un colaborador de la Administración del Estado en la satisfacción de las necesidades públicas que subyacen al contrato, ha hecho que el principio de riesgo y ventura se reconvierta sustancialmente por aplicación de la doctrina del equivalente económico o ecuación financiera del contrato, que obliga al Estado a reparar, compensar o reequilibrar la ruptura contractual, para evitar el sacrificio especial de contratista ${ }^{48}$.

En este sentido se pronuncia la Contraloría General de la República, que en el caso de un contrato de suministro para el Ejército de Chile, dictaminó que: “(...) sobre la materia además se debe estar a otros principios tales como la buena fe y la prohibición de enriquecimiento sin causa, con

\footnotetext{
${ }^{46}$ Momberg, cit. (n. 47), pp. 49-50.

${ }^{47}$ Peñailillo. cit. (n. 37), pp. 226-228.

${ }^{48}$ Cordero Vega, Luis, Lecciones de Derecho Administrativo (Santiago, Thomson
} Reuters, 2015), p. 436. 
especial atención al de equilibrio económico del contrato o de las prestaciones mutuas de las partes. Este último se traduce en el acatamiento de las condiciones fijadas para la presentación de las ofertas y de ejecución del acuerdo de voluntades, en lo que respecta a la equivalencia de las cantidades de especies entregadas y su precio".

Y concluye que: "Esta alteración ocasionó que la aplicación desfasada de la 'cláusula de reajustabilidad', en vez de mantener el justo y exacto valor del contrato -más aún tratándose de productos estacionarios, sensibles a los cambios climáticos y de difícil almacenamiento-, se tradujera en un desequilibrio económico del contrato, al tener el reclamante-según indica-, que vender al Ejército de Chile a un precio más bajo de lo que previno en su oferta y en el 'contrato', producto de la demora en la 'total tramitación del referido acto administrativo aprobatorio" ${ }^{49}$.

De este modo, la mantención del equilibrio económico-financiero del contrato administrativo, se traduce en determinar la extensión de la indemnización de los perjuicios causados por la potestad variandi, el hecho del príncipe o la teoría de la imprevisión. Es unánimemente aceptado que el contratista afectado tiene derecho a que se le indemnicen los perjuicios causados como consecuencia de algunas de estas medidas ${ }^{50}$.

Oelckers, considera que "la justificación de tal indemnización se encuentra en la responsabilidad objetiva, por la cual, la Administración está obligada a indemnizar toda lesión o perjuicio antijurídico, aunque el agente que lo ocasione obre con toda licitud" 51 .

Bajo este contexto, la necesidad de una equivalencia económica de las prestaciones se constituye como una garantía del contratante para lograr un adecuado equilibrio entre las ventajas y las cargas que le impone el contrato. De este modo, el contratista, en palabras de Jèze debe recibir una indemnización integral y no una mera ayuda parcial, sino que la ayuda debe tener la entidad de restablecer la equivalencia económica del contrato ${ }^{52}$.

La Corte Suprema ha tenido oportunidad de pronunciase sobre el alcance de mantener un adecuado equilibrio del contrato administrativo ante alteraciones sustanciales, explica el máximo tribunal que: “(...) de acuerdo a los principios de los contratos administrativos y a lo establecido en el artículo 19 de la ley de concesiones, el Estado debe indemnizar al concesionario por el rompimiento del equilibrio financiero del contrato. Este rompimiento se produce cuando se altera significativamente, el régimen económico del mismo, como dice el artículo 19 de la ya citada ley. Ello corresponde al término francés

\footnotetext{
${ }^{49}$ Dictamen 94.386, de 2014.

${ }^{50}$ Jèze, cit. (n. 36), p. 38.

${ }^{51}$ Oelckers, cit. (n. 5), p. 189.

${ }^{52}$ JÈZE, cit. (n. 36), p. 16.
} 
de boulversement conmoción del contrato, introducido por la jurisprudencia del Consejo de Estado Francés a comienzos del siglo XX. Cuando ello se produce el Estado debe venir en ayuda del concesionario, lo que ocurrirá en cualquier situación" 53 .

En efecto, ante la presencia de potestades exorbitantes es imprescindible la mantención del equivalente económico o ecuación financiera del contrato administrativo, máxime cuando sus efectos son de tracto sucesivo, por cuanto se garantiza que ante las alteraciones del objeto del contrato se hace necesario restablecer el equilibrio económico mediante el pago de las indemnizaciones adecuadas. Lo anterior descansa en el hecho que la colisión de facultades administrativas versus la estabilidad contractual produce la necesidad de que la Administración compense, a través del pago del equivalente económico, la perturbación producida en las cláusulas económicas e inmutables ${ }^{54}$.

¿Cuál es el fundamento del deber de compensar cuando se altera el equilibrio económico financiero en la contratación pública?

Un primero escenario, es que el legislador se anticipe y regule el deber de compensación, obligando a la Administración a indemnizar las alteraciones contractuales. Así por ejemplo, respecto del contrato de construcción de obra pública, el artículo 102 del DS MOP N 75, de 2004, que contiene el Reglamento del Contrato de Obra Pública, habilita a la Administración para disminuir las obras en los contratos a serie de precio unitario, reconociéndole al contratista una indemnización equivalente al 10\% de la disminución que resulte de la liquidación final del contrato. Respecto del aumento de obras, el artículo 105 del mismo cuerpo normativo, faculta al Ministerio de Obras Públicas para aumentar las obras por un importe de hasta $30 \%$ de cada partida del presupuesto de un contrato a serie de precios unitarios, reconociéndole al contratista el derecho de convenir con la autoridad los nuevos precios y plazos de la obra.

Igual disposición inspira los artículos 19 y 20 de la Ley de Concesiones de Obras Públicas (DS MOP No 900, de 1996), que regula el deber de compensar económicamente al concesionario cuando sufre alteraciones de las obligaciones contractuales, de la contraparte contractual-Ministerio de Obras Públicas- o de terceros ajenos al contrato. En primer lugar, el artículo 19 establece un mecanismo de compensación de carácter económico que el Estado confiere al concesionario, frente a actos sobrevinientes de la autoridad pública que alteren significativamente el régimen económico del

${ }^{53}$ CS, 18 de mayo de 2010, Rol No 123-10.

${ }^{54}$ Villar Palasí, José Luis, Apuntes de Derecho Administrativo (Madrid, UNED, 1974), II, p. 397. 
contrato de concesión. En segundo lugar, el artículo 20 del mismo cuerpo legal, regula un mecanismo de compensación que el Estado -Ministerio de Obras Públicas- confiere para cubrir las mayores inversiones realizadas por el concesionario producto de la aplicación de medidas unilaterales o convencionales que modifiquen las características de la obra o los servicios contratados para elevar los niveles o estándares técnicos de las exigencias del contrato.

En un segundo escenario, puede ocurrir que el legislador no regule mecanismos de indemnización ante supuestos de modificaciones contractuales excesivamente onerosas, y entregue a las partes la articulación de la fórmula compensatoria, mediante la incorporación de cláusulas de revisión de precios, siendo los contratantes los encargados de definir las causales de revisión y sus limitaciones.

Si bien, en materia de Derecho privado son admisibles las cláusulas de revisión de precios por aplicación del principio de autonomía de la voluntad, consideramos que en Derecho público, por razones de justicia distributiva estas cláusulas de revisión de precio deben considerar el interés público comprometido en el contrato administrativo y la doctrina del sacrificio especial e igualdad ante las cargas públicas. En otras palabras, no pueden quedar limitada lo que disponga una de las partes, ni ser renunciada anticipadamente, si el principio de igualdad ante las cargas públicas obliga una reparación integral del daño ${ }^{55}$.

En un tercer escenario, puede ocurrir que el legislador omite cualquier pronunciamiento sobre el deber de compensar los perjuicios causados por las modificaciones contractuales y las partes nada hayan dispuesto al respecto. En estos casos, parte de la doctrina civil entiende que el deber de indemnizar la excesiva onerosidad sobreviniente se ampara en el artículo 1546 del Código Civil, señala Momberg que: “(...) cumpliéndose los requisitos de la excesiva onerosidad sobreviniente, contraviene la buena fe y por tanto al deber de cooperación mutua que corresponde a los contratantes, la conducta de la parte que se niega a la readecuación del contrato e insiste en exigir la prestación según los términos literalmente establecidos" $\$ 56$.

Desde la óptica del Derecho público, si bien el principio de buena fe ha sido reconocido por la Contraloría General de la República como un principio que debe imperar en los contratos administrativos "tanto en su celebración como en el cumplimiento de sus disposiciones, como asimismo el equilibrio económico que debe preservarse en todo convenio

${ }^{55}$ Flores Rivas, Juan Carlos, Responsabilidad contractual del Estado: recepción del principio de reparación integral, en FERMANDOIS, Arturo - SoTo Sebastián (coords.), Sentencias Destacadas (Santiago, Libertad y Desarrollo, 2017), p. 189.

${ }^{56}$ Momberg, cit. (n. 47), p. 57. 
de carácter conmutativo" ${ }^{57}$, y que justifica el deber de compensar del Estado al particular, el fundamento sustantivo de la reparación estatal por el ejercicio de la potestad variandi, el hecho del príncipe o la teoría de la imprevisión, se encontraría en el principio de igualdad ante las cargas públicas reconocido en el artículo $19 \mathrm{~N}^{\circ} 20$ de la Constitución.

En nuestra opinión, el Estado debe indemnizar cuando la alteración del objeto del contrato por el ejercicio de la potestad variandi, el hecho del príncipe o la teoría de la imprevisión implica una afectación de la igualdad ante las cargas públicas. En efecto, cuando las nuevas obras o exigencias adicionales impuestas por la autoridad unilateralmente para elevar los estándares de servicio del contrato o la dictación de normas generales o la ocurrencia de hechos imprevisibles a las partes, deviene en una afectación de la ecuación económica financiera del contrato y en un sacrificio especial de los derechos contractuales que ceden en beneficio de toda la colectividad, surge el deber de reestablecer la relación de justicia quebrantada indemnizando los perjuicios causados.

En este sentido, Cordero Vega señala que: “(...) la teoría del equilibrio económico financiero y su garantía frente a las modificaciones imprevistas fue construida desde la teoría de la responsabilidad sin culpa, en el entendido que no era la diligencia en el cumplimiento de las obligaciones contractuales la que le daba el origen a la compensación, sino las circunstancias de que existían determinados sacrificios, fundados en razones de interés público, que podían afectar al contratista y que no era equitativo que asumiera los mayores costos" 58 .

Por lo tanto, la responsabilidad que le corresponde al Estado por la afectación del equilibrio económico financiero provendría del sacrificio especial de los derechos del particular contratista por el ejercicio de la potestad variandi, del hecho del príncipe o de la ocurrencia de la teoría de la imprevisión en beneficio del resto de la sociedad. El sacrifico especial afecta la igualdad repartición de las cargas públicas reconocida en el artículo 19 $\mathrm{N}^{\circ} 20$ de la Carta Fundamental.

Sin perjuicio de existir un escaso tratamiento de la función del principio de igual repartición de las cargas públicas en materia de contratos administrativos, a nivel de jurisprudencia constitucional desde la sentencia Rol N755, de 2008, caso Turno de Abogados, en el caso de las cargas públicas personales, ha dispuesto que éstas deben compensarse amparado en la teoría del sacrificio especial, por cuanto el principio de igualdad exige remunerar las cargas. Luego, en la causa Rol No 1.254, esa magistratura

\footnotetext{
${ }^{57}$ Dictámenes 26.538, de 1985 y 21.990 , de 1986.

${ }^{58}$ Cordero, cit. (n. 50), p. 437.
} 
conociendo de una acción de inconstitucionalidad, procede a derogar la expresión "gratuitamente"

En cuanto a las cargas patrimoniales o reales especiales impuestas a individuos específicos en su patrimonio, en favor del resto de la colectividad, el Tribunal Constitucional en los fallos denominados "Playas II y III"60, afirmó que el propietario de la franja de terreno sobre la cual la ley obliga al acceso público gratuito a las playas, conserva sin embargo derecho a una compensación económica por el Estado, sin mencionar cual era la vía jurídica para impetrar dicho beneficio ${ }^{61}$.

En el fallo Curtidos Bas S.A., Rol No 2684-2014, que se pronuncia sobre la constitucionalidad del artículo 62, inciso segundo de la Ley General de Urbanismo y Construcciones, que faculta a las municipalidades para decretar el traslado de las industrias mal ubicadas, que causen molestias o daños al vecindario, se volvió ratificar la doctrina de la reparación del daño causado por la infracción del principio de igualdad ante las cargas públicas. El Tribunal Constitucional sentenció que todas las limitaciones al ejercicio de los derechos deben poseer determinación y especificidad; no pueden afectar la esencia del derecho asegurado y, además, han de respetar el principio de igualdad, especialmente en cuanto deben estar establecidas con parámetros incuestionables. Esto es, que deben ser razonables y justificadas, de donde se sigue que han de ser mesuradas, necesarias y proporcionadas.

Ahora bien, en el caso de los contratos administrativos, se podría señalar que es la misma posición de colaborador que asume el contratista respecto del Estado, la que lo obliga a soportar -en el marco del contrato- cargas o gravámenes reales superiores para la satisfacción del interés general. Si bien, este planteamiento puede ser justificado, surge la interrogante sobre los parámetros de razonabilidad y proporcionalidad de carga pública impuesta al contratista y, en consecuencia, si el contratista colaborador del Estado debe asumir la imposición de cualquier carga en términos gratuitos e incondicionales.

Doctrinalmente, se ha señalado que la mesura o razonabilidad de la gratuidad las cargas reales impuesta en el marco de un contrato administrativo, tales como el aumento de obras o la imposición de obras extraordinarias, se encuentra asociada a la carga misma, así como en el balance entre sus consecuencias económicas desfavorables y sus consecuencias favorables para

${ }^{59} \mathrm{TC}$, Rol N ${ }^{\circ}$ 1.254- INA, 29 de julio de 2009.

${ }^{60} \mathrm{TC}, \mathrm{Rol} \mathrm{N}^{\circ} 1141$ - INA, 17 de marzo de 2009.

${ }^{61}$ Sото KLOSs, Eduardo, Acceso a las playas. ¿Un retorno al estatismo expoliador?, en Fermandois, Arturo (coord.), Sentencias Destacadas (Sanrtiago, Libertad y Desarrollo, 2009), pp. 33-34. 
la sociedad destinataria final del servicio envuelto en el contrato público ${ }^{62}$. En efecto, el hecho de no considerar indemnización en favor de contratista ante alteraciones del contrato amparadas en el interés general, para sortear el test de justicia distributiva debe ser razonable y proporcionada, en atención a las siguientes pautas o directrices de razonabilidad.

Una primera exigencia del test de razonabilidad para justificar la gratuidad de la carga impuesta consiste en determinar, si la imposición de la carga permite hacer efectiva la función pública del bien o de la actividad objeto de gravamen. En otras palabras, esta primera exigencia tiene por objetivo diagnosticar el hecho que el contratista aun cuando ha sido sujeto de una nueva carga (aumento de obra u obras extraordinaria) igualmente, puede cumplir con la finalidad envuelta en el contrato, no siendo gravosa dicha carga, por estar incorporada dentro de los riesgos propios del contrato administrativo $^{63}$. No obstante, la razonabilidad de esta exigencia como instrumento armonizador entre el interés particular y el interés general, nos parece que no repara en el hecho que los contratos administrativos son acuerdos de voluntades regidos por el artículo 1545 del Código Civil, de carácter oneroso y conmutativo, donde las obligaciones se miran como equivalentes entre el Estado y el contratista, y este último ostenta el derecho al pago íntegro del precio del contrato por el cumplimiento del objeto contractual.

Una segunda exigencia de razonabilidad para justificar la gratuidad de una carga pública, consiste en determinar si existen privilegios y beneficios que compensen el gravamen impuesto al contratista dentro del marco jurídico aplicable al sujeto gravado con la carga. Sobre este tema, el Tribunal Constitucional ha estimado que las cargas públicas sortean el test de razonabilidad, cuando junto con la carga existe un beneficio hacia el destinatario que justifica la gratuidad de aquella, citando como ejemplo el uso privilegiado de un bien nacional de uso público por un concesionario sanitario, sujeto a la obligación de asumir el traslado de las instalaciones ubicadas en la faja adyacente a caminos públicos ${ }^{64}$.

Respecto de esta segunda exigencia, tal como hemos señalado anteriormente, para comprobar la presencia de beneficios que justifiquen la imposición gratuita de una carga sobre el contratista, es necesario revisar si en la normativa específica que regula el contrato respectivo existen mecanismos de compensación por cambios derivados del ejercicio de potestades

${ }^{62}$ Ponce de León Solís, Viviana, La noción de carga pública y su función en la jurisprudencia del Tribunal Constitucional Chileno, en Revista Chilena de Derecho 42 (2015), 3, p. 861.

${ }^{63}$ TC, Rol No 56, 9 de agosto de 1988.

${ }^{64}$ TC, Rol No 1992-INA, 24 de julio de 2012. 
públicas o provenientes de hechos ajenos a las partes. En materia de obra pública, los artículos 102 y 105 del DS MOP N 75, de 2004, regulan las compensaciones específicas ante alteraciones del contrato. A su vez, en materia de concesión de obra pública, los artículos 19 y 20 del DS MOP $\mathrm{N}^{\circ} 900$, de 1996, permiten que las partes del contrato puedan arribar a compensaciones que restablezcan el equilibrio contractual. Finalmente, en los casos de ausencia de beneficios consideramos que es necesario apreciar la magnitud en la alteración del equilibrio contractual, a fin de tolerar la renuncia del derecho al precio del contratista en favor del interés general envuelto en la cagra pública.

Finalmente, respecto de la proporcionalidad de las cargas públicas, el Tribunal Constitucional ha estimado que las cargas públicas pueden estimarse proporcionales siempre que no importen privación de derecho afectado. Esto significa que, por más elevado que sea el grado de satisfacción de otros derechos o bienes constitucionales que se alcanza con la imposición de la carga, esta ha de considerarse ilícita si conlleva una privación de la propiedad del sujeto gravado. En sentido opuesto, las cargas reales que importen un grado de restricción que no pueda calificarse como privación, han de estimarse como legítimas y ajustadas a la Carta Fundamental ${ }^{65}$.

De este modo, la exigencia de compensar o indemnizar la desigualdad ante las cargas públicas emana directamente de la Constitución, tomando como referencia el principio de sacrificio especial que constituye la aplicación estricta de la justicia distributiva, en virtud del cual los daños que resulten necesarios para la producción de una utilidad colectiva no deben recaer sobre un miembro solo de la comunidad, sino que deben ser distribuidos entre todos ${ }^{66}$.

Lo anterior cobra especial interés, cuando quien sufre el sacrificio patrimonial ha asumido una función de colaboración con el Estado para la satisfacción de una necesidad pública, que, de no concurrir el particular con su voluntad, debiese el Estado asumir dicha función con sus propios

${ }^{65}$ De la jurisprudencia constitucional se puede desprender que: i) una carga constituye una auténtica privación cuando existe desplazamiento patrimonial, esto es, cuando el bien sobre el cual recae la carga no permanece en el patrimonio de su titular (TC, Rol N²299); ii) ello también ocurre cuando la medida afecta el núcleo o contenido esencial del derecho, cuando la carga no deje subsistentes las facultades de uso, goce y disposición del particular gravado con ella (TC, Rol N ${ }^{\circ} 2451$ ); y, iii) cuando la carga ocasione daños innecesarios o imponga gravámenes de magnitud considerable (TC, Rol N² 2487).

${ }^{66}$ Santamaría Pastor, Juan Alfonso, La teoría de la responsabilidad del Estado Legislador, en Revista de Administración Pública 68 (1972), p. 132. 
medios. Es precisamente la posición de colaborar del Estado que ocupa el contratista el fundamento de la obligación de compensar el desequilibrio contractual, por cuanto, el ejercicio de la potestad variandi, el hecho del príncipe o el avenimiento de un hecho imprevisible modifican las condiciones iniciales del contrato, que la única forma de evitar la avocación estatal de la función de interés general es restablecer el equilibrio contractual y mantener la vigencia del contrato.

$\mathrm{Al}$ respecto, Cassagne señala que la mantención del equilibrio económico financiero en los contratos administrativos se encuentra en directa conexión con los principios propios del Derecho administrativo, específicamente con la igualdad ante las cargas públicas. Señala, el autor argentino que este principio: “(...) conectado con la necesidad de mantener la continuidad de los servicios públicos y la realización de la obra pública configura, en rigor, el principal fundamento en que se apoyan las distintas técnicas (hecho del príncipe, revisión de precios, imprevisión, etc.) para mantener el equilibrio financiero del contrato administrativo" 67 .

Por su parte, el artículo 19 No 20 de la Carta Fundamental exige que los contratistas del Estado que sufrieran una carga pública desigual, que involucre un sacrificio especial, que no pesa sobre las demás personas, deben ser compensado por el menoscabo patrimonial que sufren por la alteración sobreviniente del equilibrio económico financiero -condiciones originales del contrato- que devienen en una afectación del derecho de propiedad.

De esta forma, si sobre el contratista recae la carga de tener que ampliar sus prestaciones originales por la modificación contractual que unilateralmente dispone la Administración contratante, o bien cumplir con el contrato pese al cambio producido en las circunstancias originalmente convenidas y previstas, ya sea a causa del álea administrativa provocada por hechos del propio Estado -factum principis-, o provengan de un álea que tiene su origen en la economía general -teoría de la imprevisión-, resulta justo, proporcionado y racional otorgarle una compensación que le permita continuar con la ejecución contractual.

\section{CONCLUSIONES}

De lo expuesto previamente, podemos arribar a las siguientes conclusiones:

1. Que es el interés general ínsito en los contratos públicos y la satisfacción de las necesidades públicas el sustento de un régimen potestativo

${ }^{67}$ CASSAgne, Juan Carlos, La intervención administrativa (2a edición, Buenos Aires, Abeledo-Perrot, 1994), p. 191. 
exorbitante al derecho común, el que permite que la Administración contratante -unilateralmente- dirija, interprete, modifique, intervenga, sancione y revoque el contrato unilateralmente. Todo ello con la finalidad precisa de satisfacer necesidades públicas mediante la contratación administrativa.

2. Que la potestad de modificación unilateral de contrato administrativo reconoce a los órganos públicos la facultad de modificar los derechos y obligaciones contractuales para dar adecuado cumplimiento a la finalidad contractual, ante nuevas exigencias del interés general. Si embargo, la potestad variandi reconoce como limitación la desnaturalización del contrato, y la mantención del equilibrio económico financiero del mismo.

3. Que los órganos públicos no podrían ampararse en la potestad variandi para alterar las partidas esenciales de un contrato administrativo, tales como el objeto, el plazo o el precio, hasta el límite de transformar el contrato en excesivamente oneroso que le impida al contratista acceder a la obtención de la legítima utilidad prevista al tiempo de proponer su oferta en el procedimiento de licitación.

4. Que el factum principis o hecho del principe no es una potestad ilimitada o absoluta, sino que reconoce como limitación la mantención del equilibrio económico financiero, que permita reequilibrar los derechos y obligaciones originalmente pactadas. A su vez, los supuestos normativos del hecho del príncipe no se encuentran restringido solo al ámbito de la industria, sino que cualquier alteración normativa, proveniente de la Administración o del legislador, que impacte los elementos esenciales del contrato es suceptible de ser invocada como causa para exigir el equilibrio contractual.

5. Que es el interés general y la satisfacción de las necesidades públicas, que sirven de sustento al régimen potestativo del contrato administrativo, el mismo fundamento que exige la presencia de garantías y derechos que le permitan a los contratistas mantener un adecuado equilibrio del contrato durante su ejecución, incluso ante alteraciones contractuales ajenas a las partes.

6. Que ante el ejercicio de la potestad variandi, el hecho del príncipe o el avenimiento de un hecho imprevible ajeno a las partes, el deber de mantener el equilibrio económico puede admitir distintas fisonomías. En primer lugar, el propio legislador puede anticipar las hipotesis de modificación contractual, que habilitan al contratista solicitar de la Administración la mantención del equilibrio económico financiero. En segundo lugar, el legislador puede habilitar a la Administración para convenir con el contratista cláusulas expresas de revisión del precio. Finalmente, ante la omisión legislativa, se acude al principio de igualdad ante las cargas públicas para sustentar la mantención del equilibrio económico financiero del contrato. 
7. Que el principio de igualdad ante las cargas públicas ha sido reconocido expresamente por la jurisprudencia del Tribunal Constitucional, exigiendo que las cargas públicas puedan ser impuestas en la medida que sean tributarias del test de razonabilidad y proporcionalidad. En efecto, son cargas públicas legítimas aquellas que no obstante su gravamen, dsiponen un régimen de beneficio o de compensación para el destinatario de las mismas.

8. Que no satisfacen el test de razonabilidad y proporcionalidad aquellas cargas públicas que imponen sacrificios sin una contraprestación que repare el derecho a obtener el pago íntegro del precio del contrato y la legítima utilidad proyectada al tiempo de formular la oferta en la etapa de licitación.

\section{BibLIOGRAFÍA}

Ariño, Gaspar, Teoría del equivalente económico en los contratos administrativos (Madrid, Instituto de Estudios Administrativos, 1968).

Bahamóndez Prieto, Felipe, Fallo Gasatacama: el cambio de circunstancias en los contratos. Quo vadis, en Fermandois, Arturo (coord.), Sentencias Destacadas (Santiago, Libertad y Desarrollo, 2008).

Cassagne, Juan Carlos, La intervención administrativa (2a edición, Buenos Aires, Abeledo-Perrot, 1994).

Cordero Vega, Luis, Lecciones de Derecho Administrativo (Santiago. Thomson Reuters, 2015).

Corral Talciani, Hernán, Contratos y daños por incumplimiento (Santiago, Abeledo Perrot, 2010).

Coviello, Pedro, El contrato administrativo: ¿lex inter partes o ius variandi?, en Revista de Derecho de la Universidad Católica del Perú 66 (2011).

De laubádere, André, Traité des contrats administratifs (2a edición, Paris, LGDJ, 1984).

Dörr Zeger, Juan Carlos, Notas acerca de la teoría de la imprevisión, en Revista Chilena de Derecho 12 (1985).

Dromi, Roberto, Licitación Pública (4a edición, Buenos Aires, Ediciones Ciudad Argentina, 2010).

Ferrada Bórquez, Juan Carlos, Las potestades y privilegios de la Administración Pública en el régimen administrativo chileno, en Revista de Derecho (Valdivia) 20 (2007), 2.

Flores Rivas, Juan Carlos, Concepto y naturaleza de la subvención en el Derecho chileno. El caso de la concesión de obra pública, en Revista de Derecho de la Universidad Católica de Valparaíso 37 (2011).

Flores Rivas, Juan Carlos, Las bases de licitación como medio de prueba en la litigación administrativa contractual, en Arancibia Mattar, Jaime - Romero Seguel, Alejandro (coord.), La Prueba en la Litigación Pública (Santiago, Librotecnia, 2016).

Flores Rivas, Juan Carlos, Responsabilidad contractual del Estado: recepción del principio de reparación integral, en Fermandois, Arturo - Soto Sebastián (coord.), Sentencias Destacadas (Santiago, Libertad y Desarrollo, 2017). 
Flores Rivas, Juan Carlos, Revisión de contratos administrativos. El adecuado equilibrio entre potestades exorbitantes y los derechos contractuales, en Laguna de Paz, José Carlos - Sanz Rubiales, Iñigo - De los Mozos y Touya, Isabel María (coords.), Derecho Administrativo e integración europea. Estudios en Homenaje al profesor José Luis Martínez López-Muñiz (Madrid, Editorial Reus, 2017).

García de Enterría, Eduardo - Fernández, Tomás Ramón, Curso de Derecho Administrativo (15 a edición, Cizur Menor, Civitas, 2011), I.

Granillo Ocampo, Raúl Enrique, Distribución de riesgos en la contratación administrativa (Buenos Aires, Editorial Astrea, 1990).

González-Varas Ibáñez, Santiago, El contrato administrativo (Madrid, Civitas, 2003).

Jèze, Gastón, Principios generales del Derecho Administrativo. Teoría general de los contratos de la Administración (Buenos Aires, Depalma, 1950), IV.

Lara, José Luis - García-Huidobro, Luis Eugenio, Sobre el régimen concesional chileno: ¿podemos hablar de un modelo de concesión?, en Soto Kloss, Eduardo (coord.), Administración y derecho: homenaje a los 125 años de la Facultad de Derecho de la Pontificia Universidad Católica de Chile (Santiago, LegalPublishing, 2014).

Loo Gutiérrez, Martín, La distribución de los riesgos en el contrato de concesión de obra pública, en Bermúdez Soto, Jorge (Editor), Perspectivas para la modenización del derecho de la contratación administrativa (Valparaíso, Ediciones Universitarias de Valparaíso, 2016), pp. 193-208.

Marienhoff, Miguel, Tratado de Derecho Administrativo (4a edición, Buenos Aires, Abeledo-Perrot, 1994), III-A.

Momberg Uribe, Rodrigo, Teoría de la imprevisión: la necesidad de su regulación legal en Chile, en Revista Chilena de Derecho Privado 15 (2010).

Moraga Klenner, Claudio, Contratación administrativa (Santiago, Editorial Jurídica de Chile, 2007).

Oelckers Camus, Osvaldo, Los principios informadores de la contratación administrativa, en Revista de Derecho de la Pontificia Universidad Católica de Valparaíso 7 (1983).

Peguignot, Georges, Théorie Générale du Contrat Administratif (París, A. Pedone, 1944).

Peñailillo Arévalo, Daniel, La revisión judicial de obligaciones y contratos en la reforma del Código Civil (La lesión y la imprevisión), en Revista de Derecho. Universidad de Concepción 208 (2000).

Ponce de León Solís, Viviana, La noción de carga pública y su función en la jurisprudencia del Tribunal Constitucional Chileno, en Revista Chilena de Derecho 42 (2015), 3.

Rodríguez, Libardo, El equilibrio económico en los contratos administrativos (Bogotá, Temis, 2012).

Santamaría Pastor, Juan Alfonso, La teoría de la responsabilidad del Estado Legislador, en Revista de Administración Pública 68 (1972).

Santamaría Pastor, Juan Alfonso, Principios de Derecho Administrativo (3a edición, Madrid, Editorial Centro de Estudios Ramón Areces, 2002), II.

Soto Kloss, Eduardo, Acceso a las playas ¿Un retorno al estatismo expoliador?, en Fermandois, Arturo (coord.), Sentencias Destacadas (Santiago, Libertad y Desarrollo, 2009).

Villar Palasí, José Luis, Apuntes de Derecho Administrativo (Madrid, UNED, 1974), II. 